\title{
Does the Servitization Strategy Improve the Performance of Manufacturing Enterprises in China?
}

\author{
Lianxing Min'1, Jianqiong Wang1*, Qian Luo ${ }^{2}$ \\ ${ }^{1}$ School of Economics and Management, Southwest Jiaotong University, Chengdu, China \\ ${ }^{2}$ Bureau of Finance, Government of Chengdu, Chengdu, China \\ Email: $\underline{\text { md3318@163.com, }}$ *qiongsi007@126.com, 122633447@qq.com
}

Received 24 April 2015; accepted 24 May 2015; published 27 May 2015

Copyright (C) 2015 by authors and Scientific Research Publishing Inc.

This work is licensed under the Creative Commons Attribution International License (CC BY). http://creativecommons.org/licenses/by/4.0/

(c) (i)

\begin{abstract}
There is a controversy of the relationship between servitization of manufacturing and business performance in the literature. Based on the data of Hu-Shen A-share listed manufacturing enterprises in 2013, this paper examined the relationship in the above with the traditional servitization level variable(SERL) and the servitization decision variable(SERD), which was generated in a dynamic perspective of strategic decision, to measure the servitization strategy. The empirical results showed that the servitization decision was positively correlated with the market performance (Tobin's q), and the servitization level was negatively correlated with the financial performance, including return on assets (ROA), economic value added change rate (EVAC) and earnings per share (EPS). Further, we discussed the results from the signal theory and diversification discount theory.
\end{abstract}

\section{Keywords}

Servitization, Business Performance, Strategic Transformation, Diversification, China

\section{Introduction}

It's becoming a new trend for the traditional manufacturing enterprise adding services to products in our times. There are $19.33 \%$ of Chinese manufacturing firms had servitized in 2011, and this ratio is $55.14 \%$ in the United States [1]. This phenomenon may have already existed in 150 years ago [2], but it gradually got the attention from scholars and mangers until it's named as servitization in 1988 [3].

\footnotetext{
"Corresponding author.
}

How to cite this paper: Min, L.X., Wang, J.Q. and Luo, Q. (2015) Does the Servitization Strategy Improve the Performance of Manufacturing Enterprises in China?. American Journal of Industrial and Business Management, 5, 281-287. 
There is no uniform definition of the term of servitization [4]. It's coined by Vandermerwe and Rada and defined as "the increased offering of fuller market packages or 'bundles' of customer focused combinations of goods, services, support, self-service and knowledge in order to add value to core product offerings" [3]. Another term on this phenomenon is servicizing, which is defined as "The emergence of product-based services, which blurs the distinction between manufacturing and traditional service sector activities" [5], or "the transformation from product-to service-based enterprise" [6]. There are also some other definitions on the two terms [4], and these definitions can be generally divided into two groups: the output view and the process view. In the output view, they think servitization of manufacturing is the change of output structure and increase of the ratio of service in the total output. But the process view emphasizes the changes in business processes and organizational structure for manufacturing enterprise. In fact, the two views are not contradictory, just like the two sides of a coin. Servitization brings the manufacturing enterprises new output structure and established on the basis of the internal organization structure adjustment. The new output structure often means the addition of services, which is similar to diversification. So there are some scholars believe that the servitization is one form of diversification strategy [7] [8]. It's necessary to reform the traditional operation mode of organization in implement process of servitization, which is seen one feature of the strategic transformation and called "service transition strategy" by scholars [9]. So we think it has the characteristics of the two strategies in the above.

What servitization could bring manufacturing enterprise is an important topic in the literature. Vandermerwe and Rada [3] considered servitization as a competitive tool and it had been changing the competitive dynamics. Servitization could set barriers to competitors, third-parties and customers. It also created the dependency, differentiated the market offering and diffused new innovations. The case study from White et al. [5] and Reiskin et al. [6] both pointed that the servicizing would drive environmental gains through the ways of product design and manufacturing methods. It is also seen a business model innovation [10] and the way to improve firm's competitive advantages using Product-Service Systems (PSS) [11]. An empirical survey of 137 companies in three West Europe countries demonstrates that service business orientations leverage relative product sales [12].

Some other scholars point out that there aren't always the positive effects of servitization on the business performance. There are also many servitized firms failed [13]. Evenly, the servitization enterprises have the lower profit than the pure manufacturing enterprises [14]. Mathieu [15] suggests that the manufacturing enterprises must consider the two new costs: competition cost and political cost, which might occur in the implementation process of servitization strategies. The evidence from more than 30 equipment manufacturing enterprises shows that extending the service business does not generate the expected correspondingly higher returns, because the operation cost and management complexity in the servitized enterprises increase substantially, this phenomenon is named "service paradox" [16]. In the context of servitization, strong emphasis on service differentiation leads to a manufacturer's strategies for customer centricity being less sensitive to increasingly complex customer needs, which can increase a firm's payoff for customer centricity [17]. The tangible service investments in process of servitization are often underestimated by manufacturers. The increasing service breadth has negative effect on profit performance, while the increasing service depth results in higher margins and an increase in market value [10].

There are a few empirical researches on investigating the relationship between servitization strategy and business performance, especially in the basis of large sample. The empirical studies also draw very different conclusions, as theoretical analysis. Neely [18] first explores the effects of servitization strategy in empirical methodology, and finds that servitization of manufacturers promotes their overall incomes, but brings a lower profit rate than pure manufacturers. Fang et al. [9] finds that in U.S., the service transition strategies indeed improve the market value of manufacturing enterprises, but it's the U-sharp rather than the simply linear relationship. There are also some researches focusing on the Chinese enterprises. Chen [8] argues that there is a significant and positive linear relationship between servitization and financial performance in U.S. manufacturers, while the inverted U-shaped relationship in Chinese enterprises. Zhou [19] finds that the servitization of manufacturing is positively related to its market share and has nothing to do with the profitability. Based on the data of International Manufacturing Strategy Survey (IMSS-V), Li et al. [20] find that the service orientation is positively related to business performance, both the return on sales ((ROI) and return on investment (ROI).

To sum up, scholars generally support the view that is the servitization strategy of manufacturing enterprise has a positive influence on its market value, but different conclusions exist about its influence on profitability. One possible reason of different conclusions is that the different measures of business performance are used in the literature [21]. The different measures contain different information contents and reflect the different aspects 
of performance. The defect of traditional measure of servitization strategy is another possible reason. No matter the ratio of service revenue in total revenue [9] or the number of service types in business description [18], just reflects the current level of servitization strategy, not the feature of strategy transition. So we generated a new measure in perspective of the change of servitization extent in a certain point, in order to investigate effects of the change o servitization in short-term on business performance.

There are also plenty of factors and their roles in the relationship between servitization strategy and business performance discussed in the literature, such as resource slack and industry turbulence [9], the organizational parameters and their moderating roles [12], the strategic alignment [22] and the socio-technical capability [23]. Though these discussions could help us to explore the effects of servitization strategy on business performance and explain the "service paradox", the conclusions are different and difficult to achieve consistency for the different theoretical perspective. So we only discuss the relationships between different indicators of servitization strategy and different aspects of business performance in this paper, and don't consider the potential impact of other factors on the relationships.

\section{Hypotheses}

In this paper, we use regression analysis to investigate the relationships between different indicators of servitization strategy and business performance, and to answer the question if the effects of servitization strategy on different indicators of business performance vary?

Based on the literature reviews and theory analysis in the above section, we propose the theory hypothesis in this paper and summarize our expectations in Table 1.

\section{Empirical Research Methodology}

\subsection{Measures}

1) Business Performance

For the potential effects of the different measures of business performance in the controversy, we investigate the effects of servitization strategy on the four different measures of business performance in the same time: Tobin's q, return on assets (ROA), economic value added (EVA) and earnings per share (EPS). Tobin's q represents the firm's market value and is a good measure of performance in the goal of enterprise value maximization. ROA and return on common stockholders' equity (ROE) is mostly used as measure of performance in the goal of enterprise profit maximization. For effects of the phenomenon of earnings management, we choose ROA to measure of profitability. EVA is another important indicator of performance evaluation and becoming popular in Chinese enterprises, especially under the promotion of the China State-owned Assets Supervision and Administration Commission (SASAC) from 2010. We use the change rate of EVA to measure the impact of servitization strategy on the growth of firm financial performance. EPS can reflect both the profitability and investment value of the stock, and it contains the different information of enterprise management from the Tobin's q and can be the indicator of robust test for ROA.

2) Servitization Strategy

There are three main measure used in the literature: questionnaire, the ratio of service revenue in total revenue and business description analysis. We select and improve the last method, which is mostly used in the literature. It has three defects: the limited types of service, analysis only on the listed enterprise itself and low accuracy of the automatic analysis by software. In the paper of Neely et al. [1], they identified 12 different types of service in the extent of servitization, but all of the 12 types of service were related to products. Considering the emergence of new service types and the service unrelated to products, we identify 15 different types of service in this paper. Enterprise group has become the norm in enterprise organization structure, many listed enterprises initiate new business through its subsidiary, and Wuliangye (000858) is a good example of this phenomenon [24]. So we ex-

Table 1. The relationships between the servitization and business performance.

\begin{tabular}{ccccc}
\hline Variables & Tobin's q & EVAC & EPS & + \\
\hline SERD & + & + & + & + \\
SERL & $+/-$ & $+/-$ & $+/-$ \\
\hline
\end{tabular}

a. + represents the positive correlation; - represents the negative correlation. 
tend the analysis to the subsidiary of listed enterprises appeared in its financial statements. We also use manual text analysis instead of automatic analysis by software to improve analysis accuracy.

Another innovation in methodology is the new variable of the servitization decision (SERD) generated in this paper. It, as a new measure of servitization strategy, is to characterize its feature of strategic transformation. The traditional measure, named of servitization level variable (SERL), is to characterize its feature of diversification strategy.

3) Control Variables

The business performance of enterprises in different industries, age and size are varied. So we control the three variables in the process of regression analysis. The industry (IND) is measured by the code of industry classification standard of the China Securities Regulatory Commission (CSRC). We use the natural logarithm of the age from the date of initial public offerings as the measure of the variable Age, and the natural logarithm of the total asset as the measure of the variable of Size.

\subsection{Data}

Our investigation focus on the economic effects of servitization strategy of the A-share listed manufacturing enterprises on Shanghai and Shenzhen stock market in 2013. We get 680 samples in the following criteria: 1) choosing the manufacturing enterprises based on the industry classification standard of CSRC; 2) excluding all ST and PT enterprises; 3) excluding all enterprises existing data missing; 4) data are combined into one when there are more than one announcement on the change of business description.

The data used in this paper is drawn from CSMAR database, as well as the annual reports of listed enterprises. The CSMAR database consists of financial data of all listed enterprises on Chinese stock market. We obtain the business description from the annual reports of listed enterprises, and analyze the change of business description based on the relevant announcement. In accordance with the provisions of CSRC, the enterprise must release an announcement, when its business description changed.

\section{Empirical Analysis}

\subsection{Descriptive Statistics and Correlation Analysis}

Table 2 shows the descriptive statistics results and correlation of all variables. It can be found that SERD and SERL are significantly related to the business performance variables. It proves the hypotheses are reasonable and suitable for regression analysis.

\subsection{Model Tests}

We use the OLS regression model to test the hypothesis in this paper. The multiple linear regression analysis is more suitable because there are independent variables in each model, including the SERD or SERL and the three

\begin{tabular}{|c|c|c|c|c|c|c|c|c|c|}
\hline & SERD & SERL & Tobin's q & EVAC & EPS & ROA & IND & AGE & SIZE \\
\hline SERD & 1.000 & -0.025 & $0.077^{* *}$ & 0.030 & -0.034 & -0.005 & 0.037 & $-0.090^{* *}$ & $-0.074^{*}$ \\
\hline SERL & & 1.000 & $-0.074^{*}$ & -0.061 & $-0.083^{* *}$ & $-0.093^{* *}$ & $0.102^{* * * *}$ & 0.026 & $0.151^{* * *}$ \\
\hline Tobin's q & & & 1.000 & $-0.096^{* *}$ & $0.132^{* * *}$ & $0.493^{* *}$ & 0.001 & $0.127^{* * *}$ & $-0.121^{* * *}$ \\
\hline EVA & & & & 1.000 & 0.045 & 0.027 & -0.001 & -0.031 & $0.072^{*}$ \\
\hline EPS & & & & & 1.000 & $0.603^{* * *}$ & $-0.123^{* * *}$ & 0.050 & $0.296^{* * *}$ \\
\hline ROA & & & & & & 1.000 & $-0.093^{* *}$ & 0.018 & -0.037 \\
\hline IND & & & & & & & 1.000 & -0.038 & -0.006 \\
\hline AGE & & & & & & & & 1.000 & $0.159^{* * *}$ \\
\hline Mean & 0.130 & 3.530 & 1.675 & -0.628 & 0.609 & 0.073 & 59.030 & 2.640 & 21.649 \\
\hline S.D. & 0.522 & 1.827 & 0.822 & 15.938 & 0.421 & 0.037 & 23.211 & 0.339 & 1.073 \\
\hline
\end{tabular}

a. There are Pearson correlation coefficients and descriptive statistics results in the table; ${ }^{*}$ represents significance in $10 \%$ level; ${ }^{* *}$ represents significance in $5 \%$ level; ${ }^{* * *}$ represents significance in $1 \%$ level. 
control variables in the above. It's needed to conduct multicollinearity test and heteroscedasticity test for multiple linear regression analysis with a cross-sectional data. The maximum values of variance inflation factor (VIF) in Table 3 can explain that there isn't multicollinearity in all models. The White test results also show that the heteroscedasticity doesn't exist in these models. We delete the models of EVAC-SERD and ROA-SERD for their F-values are only 1.39 and 1.77 and don't meet the significance in $10 \%$ level, which mean the poor fitting effects.

\subsection{Regression Results Analysis}

The regression analysis results are showed in Table 3. It's obviously that the SERD are positively related to the Tobin's q, but have nothing to do with the EPS. Meanwhile the SERL is negatively related to the ROA, EVAC and EPS, but has nothing to do with Tobin's q. The results partially validate hypotheses in Section 2, and the different effects of SERD and SERL can be seen the difference between short-term and long-term effects of servitization strategy on business performance.

We think that the empirical results can be explained from the following aspects.

1) The positive relationship between SERD and Tobin's q shows the positive role of servitization strategy decision in promoting its market value. We think that the reasons for this result can be discussed by the signal theory. When the enterprise decided to adapt a new servitization strategy, it must revise its business description and release relevant announcement. The information in the announcement would be recognized by the investors in the market as a positive effort to improve business performance. It's so common that good news brings the market premium in any market around the world. Meanwhile the implementation of servitization strategy often needs a lot of new investment, but it always takes some time to recover the new investment. So we can't immediately see the substantive contribution to profits after the decision of servitization strategy made. That may be the reason that why there is no significant positive correlation between SERD and EPS.

2) The relationships between SERL and EVAC, EPS and ROA can be explained by diversified paradox. In the view of servitization strategy as one form of diversification strategy, the SERL is higher, the level of diversification is higher. The view of diversified paradox is that the excessive diversification would damage the enterprise's business performance, and it has been verified that diversification is negatively related to the ROA [25]. So the negative relationship between SERL and financial indicators in this paper can be seen another evidence of diversified paradox. It also verified the view of "service paradox" and "servitization paradox". The excessive servitization would add the complexity of management [16] and the enterprise would lose the strategic focus [9]. Under the resource and management ability constrains, the enterprise is hard to improve the business performance.

3) Why don't the positive effects of SERL on the market value exist? One possible explanation is that the damage of excessive servitization to profitability. Enhancement of the servitization level is a long-term process. In the short term the market value would rise after the enterprise decides to adapt a new servitization strategy,

\begin{tabular}{|c|c|c|c|c|c|c|}
\hline \multirow{2}{*}{$\begin{array}{l}\text { Independent } \\
\text { Variables }\end{array}$} & \multicolumn{6}{|c|}{ Dependent Variables } \\
\hline & Tobin’s q & Tobin’s q & EVAC & EPS & EPS & ROA \\
\hline SERD & $0.126^{* *}(2.12)$ & & & $-0.007(-0.22)$ & & \\
\hline SERL & & $-0.027(-1.54)$ & $-0.645^{*}(-1.90)$ & & $-0.028^{* * *}(-3.24)$ & $-0.002^{* *}(-2.07)$ \\
\hline IND & $0.000(0.07)$ & $0.000(0.30)$ & $0.004(0.15)$ & $-0.002^{* * *}(-3.31)$ & $-0.002^{* * *}(-2.99)$ & $-0.000^{* *}(-2.18)$ \\
\hline AGE & $0.379^{* * * *}(4.09)$ & $0.365^{* * * *}(3.94)$ & $-2.040(-1.12)$ & $-0.003(-0.07)$ & $-0.002(-0.03)$ & $0.002(-0.73)$ \\
\hline SIZE & $-0.107^{* * *}(-3.66)$ & $-0.104^{* * *}(-3.52)$ & $1.343^{* *}(2.31)$ & $0.116^{* * *}(7.99)$ & $0.123^{* * *}(8.47)$ & $-0.001(-0.73)$ \\
\hline Adj $R^{2}$ & 0.037 & 0.034 & 0.007 & 0.097 & 0.111 & 0.011 \\
\hline F-Value & $7.56^{* * *}$ & $7.02^{* * *}$ & $2.12^{*}$ & $19.29^{* * * *}$ & $22.2^{* * *}$ & $2.86^{* *}$ \\
\hline Max VIF & 1.034 & 1.049 & 1.049 & 1.034 & 1.049 & 1.049 \\
\hline
\end{tabular}

a. There are standard coefficients in the table and T-values in parentheses; ${ }^{*}$ represents significance in $10 \%$ level; ${ }^{* *}$ represents significance in $5 \%$ level; represents significance in $1 \%$ level. 
but the management costs increases and profitability decreases with the enhancement of the servitization level in the long term. The valuation of the enterprise's market value of the enterprise will be restored to the original level, when the investors couldn't see positive effects of servitization on its profitability.

\section{Conclusions}

In this paper, we have discussed the relationship between the servitization strategy and business performance in China's listed manufacture enterprise. The empirical results show that the implement of servitization strategy is a long-term gradual transformation process, and its effects on business performance vary in different stages. There's no evidence that it promotes the listed enterprise's profitability in China. The financial performance isn't affected when the servitization strategy decision is made. Even more, it's negatively related to the servitization level in the perspective of long term. Though the servitization strategy doesn't promote the enterprise's financial performance, the decision of servitization strategy is regarded as good news by the stock market and brings market value premium in current year. The market value premium disappears with the servitization level increasing and loss of profitability.

Based on the empirical results, we suggest that manufacturing enterprises should focus on the integration of services and products, when carry out the servitization strategy. It should be the key point that providing high value-added complex service for consumers, rather than rushing to expand the service business scope by a large number of superficial services. The implement of servitization strategy could reduce the traditional business risks, but bring other new risks. When enterprises provide simple services, the effects of new risks will beyond the benefits, but it wouldn't appear when enterprises provide complex services [13].

\section{Acknowledgements}

Authors would like to acknowledge the financial support from the National Social Science Foundation of China (No. 2011XGL0001), Science and Technology Plan Project of Sichuan Province (No.2012ZR0024) and Humanities and Social Science Project of Education Department of Sichuan Province (No. 14SB0507, No. 14SB0508).

\section{References}

[1] Neely, A., Benedettini, O. and Visnjic, I. (2011) The Servitization of Manufacturing: Further Evidence. 18th European Operations Management Association Conference, Cambridge, 3-6 July 2011.

http://www.cambridgeservicealliance.org/uploads/downloadfiles/2011-The\%20servitization\%20of\%20manufacturing. pdf

[2] Schmenner, R.W. (2009) Manufacturing, Service, and Their Integration: Some History and Theory. International Journal of Operations \& Production Management, 29, 431-443. http://dx.doi.org/10.1108/01443570910953577

[3] Vandermerwe, S. and Rada, J. (1989) Servitization of Business: Adding Value by Adding Services. European Management Journal, 6, 314-324. http://dx.doi.org/10.1016/0263-2373(88)90033-3

[4] Baines, T.S., Lightfoot, H.W., Benedettini, O. and Kay, J.M. (2009) The Servitization of Manufacturing: A Review of Literature and Reflection on Future Challenges. Journal of Manufacturing Technology Management, 20, 547-567. http://dx.doi.org/10.1108/17410380910960984

[5] White, A.L., Stoughton, M. and Feng, L. (1999) Servicizing: The Quiet Transition to Extended Product Responsibility. Tellus Institute, Boston, 97.

[6] Reiskin, E.D., White, A.L., Johnson, J.K. and Votta, T.J. (1999) Servicizing the Chemical Supply Chain. Journal of Industrial Ecology, 3, 19-31. http://dx.doi.org/10.1162/108819899569520

[7] Visnjic, I. and Van Looy, B. (2009) Manufacturing Firms Diversifying into Services: A Conceptual and Empirical Assessment. Proceedings of the 20th POMS conference, Orlando, 1-4 May 2009. http://pomsmeetings.org/confproceedings/011/fullpapers/011-0730.pdf

[8] Chen, J.X. (2010) An Empirical Test of the Effect of Manufacturing Service-Orientation on Corporate Performance: A Comparison between Chinese and American Enterprises. Journal of Business Economics, 1, 33-41. (In Chinese)

[9] Fang, E., Palmatier, R.W. and Steenkamp, J.B.E. (2008) Effect of Service Transition Strategies on Firm Value. Journal of Marketing, 72, 1-14. http://dx.doi.org/10.1509/jmkg.72.5.1

[10] Visnjic, I., Neely, A. and Wiengarten, F. (2012) Another Performance Paradox?: A Refined View on the Performance Impact of Servitization. ESADE Business School Research Paper No. 231. 
[11] Meier, H., Völker, O. and Funke, B. (2011) Industrial Product-Service Systems (IPS2). The International Journal of Advanced Manufacturing Technology, 52, 1175-1191. http://dx.doi.org/10.1007/s00170-010-2764-6

[12] Antioco, M., Moenaert, R.K., Lindgreen, A. and Wetzels, M.G.M. (2008) Organizational Antecedents to and Consequences of Service Business Orientations in Manufacturing Companies. Journal of the Academy of Marketing Science, 36, 337-358. http://dx.doi.org/10.1007/s11747-008-0085-1

[13] Benedettini, O., Swink, M. and Neely, A.D. (2010) Why Do Servitized Firms Fail? A Risk-Based Explanation. International Journal of Operations \& Production Management, 35, 946-979. http://dx.doi.org/10.1108/IJOPM-02-2014-0052

[14] Grönroos, C. and Ojasalo, K. (2004) Service Productivity: Towards a Conceptualization of the Transformation of Inputs into Economic Results in Services. Journal of Business Research, 57, 414-423. http://dx.doi.org/10.1016/S0148-2963(02)00275-8

[15] Mathieu, V. (2001) Service Strategies within the Manufacturing Sector: Benefits, Costs and Partnership. International Journal of Service Industry Management, 12, 451-475. http://dx.doi.org/10.1108/eum0000000006093

[16] Gebauer, H., Fleisch, E. and Friedli, T. (2005) Overcoming the Service Paradox in Manufacturing Companies. European Management Journal, 23, 14-26. http://dx.doi.org/10.1016/j.emj.2004.12.006

[17] Gebauer, H., Gustafsson, A. and Witell, L. (2011) Competitive Advantage through Service Differentiation by Manufacturing Companies. Journal of Business Research, 64, 1270-1280. http://dx.doi.org/10.1016/j.jbusres.2011.01.015

[18] Neely, A. (2008) Exploring the Financial Consequences of the Servitization of Manufacturing. Operations Management Research, 1, 103-118. http://dx.doi.org/10.1007/s12063-009-0015-5

[19] Zhou, Y.C. (2010) Research on the Implementation of Servitization Strategy of Manufacturing Enterprise and Its Impact on the Performance. Ph.D. Thesis, Northwest University, Xi'an. (In Chinese)

[20] Li, H.T., Li, H.S. and Tian, Y.Z. (2013) The Impact Mechanism of the Servitization of Manufacturing on Business Performance. Journal of Harbin Engineering University, 34, 933-938. (In Chinese)

[21] Xu, L.P., Xin, Y. and Chen, G.M. (2006) The Types of Controlling Shareholders and the Performance for China's Listed Companies. The Journal of World Economy, 29, 78-96. (In Chinese)

[22] Hu, C.P. and Wang, T. (2013) Servitization of Manufacturing Companies: Does the Service Delivery Really Improve Performance of the Manufacturing Company? Economic Management, 35, 68-76. (In Chinese)

[23] Hu, C.P. and Wang, T. (2013) The Socio-Technical Capacity in Manufacturing Services Delivery and Its Influence on Manufacturing Firm Performance. Forum on Science and Technology in China, 29, 55-60. (In Chinese)

[24] Min, L.X., Liu, R.H. and Wang, J.Q. (2015) Servitization of Manufacturing Enterprises in China: Status and Features. Science and Technology Management Research, Forthcoming. (In Chinese)

[25] Chakrabarti, A., Singh, K. and Mahmood, I. (2007) Diversification and Performance: Evidence from East Asian Firms. Strategic Management Journal, 28, 101-120. http://dx.doi.org/10.1002/smj.572 